\title{
KLÍČOVÁ SPECIFIKA ORGANIZACÍ NEVÝDĚLEČNÉHO SEKTORU
}

\author{
Iris Šimíková
}

\section{Klíčová slova:}

vize, poslání, cíle, nevýdělečný sektor, státní nevýdělečná organizace, nestátní nevýdělečná organizace, právnická osoba, účetní jednotka, daň z př́ijmů právnických osob, veřejná prospěšnost

\section{Key words:}

vision, mission, objectives, non-profit sector, government non-profit organization, not-forprofit non-government organization, legal entity, accounting entity, corporate income tax, public utility

\begin{abstract}
Abstrakt
Primárním cílem nevýdělečných organizací je naplnění poslání nepřinášející přímý zisk, ale užitek v modifikaci veřejně prospěšné služby. Typologie nevýdělečného sektoru prezentuje specifické postavení organizací v národním hospodářství. Organizace jsou považovány za účetní jednotky a daňové poplatníky. Výjimky mají zdůraznit vizi neziskovosti v kontextu tržního prostředí. Identifikace klíčových specifik je nezbytná pro orientaci v rozsáhlé legislativě.
\end{abstract}

\begin{abstract}
The primary objective of non-profit organizations is impletion of the envoi which isn't make direct earnings, but provides benefit in modification of public utility services. Typology of non-profit sector presents specific position of the organizations in the national economy. Organizations are considered as business units and taxpayers. The exceptions should emphasize the non-profit vision in context of the market environment. The identification of the main specifics is necessary for orientation in the massive legislation.
\end{abstract}

\section{Úvod}

Právnické osoby jsou zakládány $\mathrm{v}$ důsledku snah o dosažení společných cílů zájmovou skupinou osob. Pro naplnění těchto záměrů jsou využívány duševní hodnoty a potenciál, který je v držení těchto subjektů. Nejčastější formou jsou obchodní společnosti, založené za účelem podnikání, které při provádění ekonomických činností naplňují společné cíle vedoucí k dosažení zisku. Pravidla jejich fungování jsou stanovena legislativními předpisy.

Klíčovým specifikem jinak hodnotově orientované skupiny subjektů není primárně dosažení zisku při uskutečňování aktivit, ale poskytování veřejně prospěšných služeb naplněním svého specifického poslání, bez ohledu na dosažený výsledek hospodaření. Pro označení těchto subjektů se nejčastěji používají dva pojmy a to organizace neziskové nebo organizace nevýdělečné, kdy v názvu je vyjádřen základní rozdíl mezi podnikatelským a neziskovým sektorem. Případný kladný výsledek hospodaření v podobě zisku není odveden zakladatelům, ale slouží k dalšímu rozšsiřrení poskytování prospěšných služeb. Pro vymezení jejich statusu lze konstatovat, že se jedná o právnické osoby, účetní jednotky a mnohdy poplatníky daně prŕjmů právnických osob i jiných daní. 
Cílem článku je metodou deskripce identifikovat klíčová specifika nestátních nevýdělečných organizací v současném tržním prostředí, kdy snahou občanů pod vlivem negativní situace je zakládání organizací, hájících jejich společné zájmy. Neznalost teoretických klíčových specifik může podstatným způsobem ovlivnit jejich rozhodování.

\section{Terminologické uvedení}

Organizace, které ve svém cíli mají stanoveno poslání, jsou označovány názvem „neziskové“ [3], někteří autoři naopak užívají označení „nevýdělečné“ [4]. Lze konstatovat, že neexistuje v současné legislativě jednotné vymezení. Společným sjednocujícím prvkem těchto organizací je naplnění jejich vize. Vize je spojována s představou, zpravidla pozitivních úkonů, majících za účinek př́iznivé konání ve prospěch zainteresovaných osob. Vize zpravidla nemá přesně vyhraněné postupy při jejím uskutečňování. Vyšším stupněm vize je poslání, $\mathrm{v}$ tomto případě již jsou nastavena kriteria, vybrány vhodné prostředky a nástroje $\mathrm{k}$ jejich dosažení a je prosazován konzistentní postup, směřující k dosažení poslání. Prosazované hodnoty poslání mohou být utříděny do formy kodexu.

„Definice poslání nevýdělečné organizace (vymezení základního účelu a tomu odpovídajícího předmětu činnosti, vymezení hlavní a vedlejší činnosti, obecně prospěšných služeb nebo cílů) musí být jasné a definované ve zřizovacích listinách, stanovách, zakládacích smlouvách či zakládacích listinách, v zákonech. Poslání je smyslem existence organizace“ [ [ 4 s. 9]. Urbancová a Kryšková používají označení nevýdělečná organizace a současně v definici zdůrazňují základní problémy v souvislosti se zdaňováním činností.

Označení poslání jako neziskové činnosti není plně vystihující, nebot' i tyto organizace při svých aktivitách mohou dosahovat zisku. Pojem nezisková organizace nevystihuje plně záměr při založení, i když zisk je přijímán a využíván. Zákon o daních z příjmů [12] v $§ 18$ odst. 3 uvádí poplatníky, kteří nejsou založeni nebo zřízeni za účelem podnikání s odkazem na obchodní zákoník, který v $§ 2$ odst. 1 definuje podnikání jako soustavnou činnost prováděnou samostatně podnikatelem vlastním jménem a na vlastní odpovědnost za účelem dosažení zisku. Je zde použita negace podnikání pro vymezení statusu daňového poplatníka právnické osoby. Lze konstatovat, že definici postihující všeobecně organizace neziskového sektoru v současné době legislativa neposkytuje. $\mathrm{Z}$ toho lze odvozovat př́činu problémů, které v těchto organizacích vznikají v souvislosti s jejich různorodými činnostmi.

Autorka článku v dalším textu se přiklání k používání označení nevýdělečné organizace (dále jen NO), z důvodu výstižnějšího označení podstaty činnosti. Pro zdůvodnění uvádí fakta, pokud osoby chtějí primárně dosáhnout osobního prospěchu, sdružují se za účelem dosažení zhodnocení vloženého kapitálu vytvořením zisku, tedy provádí výdělečnou činnost podnikají. Pokud chtějí dosáhnout prospěchu pro jiné osoby, provádí činnost na bázi primárně prospěšné činnosti, nezaměřují se prioritně na zisk, ale na jednání ve prospěch druhých osob. Avšak autorka uznává, že ani označení nevýdělečná organizace přesně nepostihuje jádro původního záměru těchto společně orientovaných osob, dle jejího názoru ale více vystihuje podstatu cíle při založení. Z těchto argumentů je patrná absence $\mathrm{v}$ jednotnosti pojmů pro tuto oblast nepodnikatelských aktivit a přetrvávající rozpory mezi užívanými názvy.

\section{Oprávněnost existence nevýdělečného sektoru}

Každý občan České republiky má právo se sdružovat dle oblasti svých zájmů. Právo na svobodné sdružování vychází z ustanovení Listiny základních práv a svobod [5]. Pokud tedy 
skupina osob majících společné zájmy se rozhodne za účelem optimálního prosazení svých cílů založit sdružení, bude tak konat dle právních předpisů, které těmto sdružením přiznávají status právnické osoby. Organizace disponuje dle svých možností daným rozsahem majetku a finančních prostředků, jehož stav a změny musí prokazovat zpravidla pomocí účetnictví a v ročních intervalech dosažené výsledky předkládat formou daňového přiznání $\mathrm{k}$ dani $\mathrm{z}$ příjmů. Z hlediska legislativy platí pro nestátní nevýdělečné organizace stejné zákony jako pro ostatní právnické osoby. Vlastním rozhodováním tak naplňují základní principy demokratického státu.

Státní nevýdělečné organizace zajišt’ují výkon veřejné správy. Veřejná správa je tvořena souborem institucí, jejichž cílem je konat ve veřejném zájmu. Jednotlivé instituce disponují svěřeným majetkem a pravomocemi k dosažení stanovených cílů. Veřejná správa se člení na státní správu a samosprávu.

Obě části sektoru nevýdělečných organizací tedy mají společný cíl a tím je konání v zájmu veřejné prospěšnosti. Lze konstatovat opět současnou absenci definice tohoto již běžně užívaného pojmu.

\section{Typologie nevýdělečných organizací}

Nevýdělečné organizace jsou zakládány s cílem naplnění specificky vymezeného poslání $\mathrm{v}$ oblastech, na které se $\mathrm{z}$ určitého důvodu nezaměřují podnikatelské subjekty. Tímto důvodem je zpravidla vysoká míra pravděpodobnosti ztrátovosti. Poskytování veřejně prospěšných služeb by mělo být doménou státních organizací s tím, že tuto oblast doplňují vhodným způsobem nestátní organizace. Stát si přitom ponechává právo rozhodnutí, zda navrhovaná organizace volí přiměřený cíl, který nezasahuje do práv jiných občanů. Pro následující členění nevýdělečných organizací bylo použito účetní hledisko, rozdělující NO do dvou základních skupin:

- státní nevýdělečné organizace; u kterých je zakladatelem stát, případně jeho organizační složky. Tuto oblast článek záměrně pomíjí, nebot' od roku 2009 se začala uskutečňovat reforma účetnictví veřejných financí, která je rozložena do několika let a změny průběžně probíhají. Dle již platných změn se tyto organizace $\mathrm{z}$ hlediska účetnictví nazývají „některé vybrané účetní jednotky“ [7] a patří k nim územní samosprávné celky, dobrovolné svazky obcí, regionální rady regionů soudržnosti, př́íspěvkové organizace, státní fondy dle rozpočtových pravidel, Pozemkový fond České republiky a organizační složky státu. Z aspektu účetnictví tyto vymezené organizace se řídí od roku 2010 novou vyhláškou pro některé vybrané účetní jednotky [10].

- nestátní nevýdělečné organizace; u kterých jsou zakladateli fyzické nebo právnické osoby, stanovují si poslání a na tuto oblast z důvodu její specifičnosti se zaměřuje článek. Z aspektu účetnictví se tyto vymezené organizace již od roku 2003 řídí vyhláškou [9]. 


\section{Obrázek 1 Základní typologie nevýdělečných organizací}

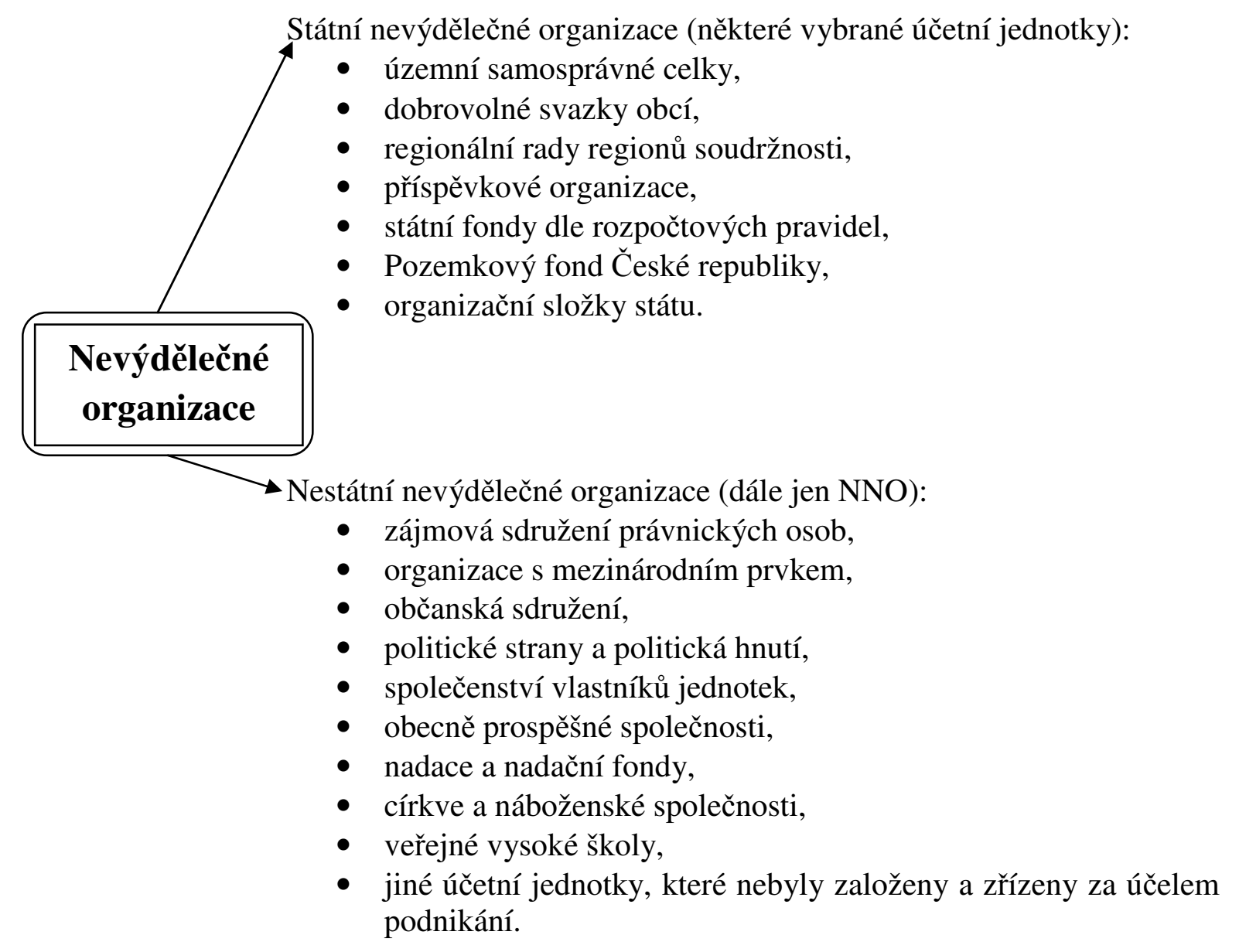

Zdroj: vlastní zpracování

Spektrum NNO je velmi rozmanité a metodicky nejednotné. Postupným vydáváním dalších zákonů se rozšiřrovaly typy organizací, které nevykazují znaky podnikání a jejich existence je dána zvláštním zákonem. Organizace jsou zakládány dle konkrétních zákonů, které mají svá specifika a současně se organizace musí řídit obecně platnými zákony vztahujícími se na všechny subjekty, jejichž znalost je nezbytná pro praktickou činnost. Tato oblast je př́ičinou největšího pochybení, kdy znalosti odpovědných osob v organizaci nejsou na dostatečné výši, jak vyžaduje právní prostředí. Jedná se zejména o legislativu v oblasti účetnictví, daní, odměňování za práci a souvisejících povinných úkonů. V tomto rozporu mezi primárním vizionářským posláním organizací a podmínkami tržního prostředí, tkví dle názoru autorky hlavní příčina problémů, které vznikají v důsledku požadavků na organizace kladených ze strany účetní a daňové legislativy.

Zájmová sdružení právnických osob vytvárí právnické osoby k ochraně svých zájmů nebo $\mathrm{k}$ dosažení jiného účelu v souladu s ustanoveními občanského zákoníku. Sdružení se zakládá písemnou zakladatelskou smlouvou, musí být přiloženy stanovy, které mimo jiné obsahují předmět činnosti sdružení. Registr sdružení je veden u krajských úřadů [14] a zápisem do registru nabývá sdružení právní způsobilosti. Dle občanského zákoníku je tedy povoleno všem právnickým osobám zakládat zájmové sdružení k jakémukoliv účelu [2]. 
Organizace s mezinárodním prvkem jsou legislativně upraveny zákonem č. 116/1985 Sb., o podmínkách činnosti organizace s mezinárodním prvkem v Československé socialistické republice, ve znění pozdějších předpisů. Žádost o povolení organizace se podává na Ministerstvo vnitra, př́ipojí se stanovy. Př́kladem je Organizace pro ekonomickou spolupráci a rozvoj (OECD).

Občanská sdružení jsou legislativně upraveny zákonem č. 83/1990 Sb., o sdružování občanů ve znění pozdějších předpisů. Zákon upravuje právo občanů se svobodně sdružovat (zakládat spolky, společnosti, svazy, hnutí, kluby, odborové organizace a jiná občanská sdružení). Nevztahuje se na sdružování občanů k výdělečné činnosti; v politických stranách (hnutích); v komorách a v církvích. Sdružení jsou právnickými osobami; práva a povinnosti člena upravují stanovy; členy mohou být i právnické osoby. Sdružení vzniká registrací podanou na Ministerstvo vnitra, k návrhu na registraci se prripojují stanovy, ve kterých se uvádí cíle činnosti, zásady hospodaření a další [16].

Činnost politických stran a politických hnutí jsou upravena zákonem č. 424/1991 Sb., o sdružování v politických stranách a v politických hnutích, ve znění pozdějších předpisů. Návrh na registraci se podává Ministerstvu vnitra, k návrhu se připojují stanovy (organizační řád), ve kterých se mimo jiné uvádí programové cíle, zásady hospodaření [2]. Rejstřík stran a hnutí vede Ministerstvo vnitra. Strana a hnutí vedou účetnictví. Nesmí podnikat vlastním jménem, ale mohou založit obchodní společnost s vybraným předmětem činnosti napřr. publikační a propagační činnost, provozování vydavatelství, nakladatelství a další taxativně jmenované předměty činnosti.

Společenství vlastníků jednotek se řídí zákonem č. 72/1994 Sb., kterým se upravují některé spoluvlastnické vztahy $\mathrm{k}$ budovám a některé vlastnické vztahy k bytům a nebytovým prostorům a doplňují některé zákony (zákon o vlastnictví bytů), ve znění pozdějších předpisů. Společenství vlastníků jednotek je právnická osoba, která vzniká zápisem vkladů jednotlivých vlastníků do katastru nemovitostí, registruje se do rejstř́íku společenství vlastníků jednotek vedeného soudem pro vedení obchodního rejstř́iku [4]. Ve stanovách se uvádí cíl ochrana práv vlastníků, povinnost vedení účetnictví a další.

Obecně prospěšné společnosti patří mezi klasické představitele nevýdělečných organizací, jež ve svém názvu mají stanovené poslání poskytování prospěchu společnosti. Přri svých aktivitách vychází ze zákona č. 248/1995 Sb., o obecně prospěšných společnostech, ve znění pozdějších předpisů [15]. Zakládací listina, která je registrována u rejstř́kového soudu v rejstříku obecně prospěšných společností, obsahuje mimo jiné druh obecně prospěšných služeb, které bude společnost poskytovat. Zakladateli společnosti mohou být fyzické osoby, Česká republika nebo právnické osoby. Pokud budou poskytovány služby, k jejichž provádění jsou potřebné zvláštní podmínky (mají se na mysli napřs. podmínky stanovené živnostenským zákonem), tyto musí být prokázány. Ve statutu se uvádí mimo jiné předmět činnosti, kdy u těchto organizací se výslovně uvádí možnost provádět doplňkové činnosti. Doplňkové činnosti je možno provádět za účelem účinnějšího využití prostředků a zároveň nedojde k omezení poskytování služeb, k jejichž poskytování byla společnost založena [8].

Nadace a nadační fondy se řídí ustanoveními zákona č. 227/1997 Sb., o nadacích a nadačních fondech a o změně a doplnění souvisejících zákonů (zákon o nadacích a nadačních fondech) ve znění pozdějších předpisů. Jedná se o účelová sdružení majetku, kdy nadace používá k dosahování účelu, za kterým byla zřízena výnosy z nadačního jmění a ostatní majetek nadace, nadační fond používá k dosahování účelu veškerý svůj majetek. Nadace a nadační 
fondy se zřizují za účelem dosahování obecně prospěšných cílů, kterými se rozumí zejména rozvoj duchovních hodnot, ochrana lidských práv nebo jiných humanitárních hodnot, ochrana přírodního prostředí, kulturních památek a tradic a rozvoj vědy, vzdělání, tělovýchovy a sportu. Nadace a nadační fond mohou být zřízeny ze závěti formou notářského zápisu. Vznikají dnem zápisu do nadačního rejstř́íku, který vede soud vedoucí obchodní rejstřík. Statut nadace nebo nadačního fondu upravuje mimo jiné podmínky pro poskytování nadačních příspěvků osobám, za účelem, ke kterému byla nadace nebo nadační fond zřízen.

Církví a náboženskou společností se rozumí dle zákona č. 3/2002 Sb., o církvích a náboženských společnostech ve znění pozdějších předpisů, dobrovolné společenství fyzických osob založené za účelem vyznávání určité náboženské víry. Činnost nemůže vyvíjet církev a náboženská společnost v rozporu s právními předpisy a její činnost nesmí ohrožovat práva, svobody a rovnoprávnost občanů. Právnickou osobou se stávají registrací na Ministerstvu kultury, které vede aktuální Rejstř́k registrovaných církví a náboženských společností, Rejstřík svazů církví a náboženských společností a Rejstřík církevních právnických osob, do kterých se zapisují zákonem stanovené údaje a jejichž součástí je sbírka listin předkládaných církvemi a náboženskými společnostmi a svazy církví a náboženských společností . V základním dokumentu církve a náboženské společnosti je mimo jiné uvedeno poslání.

Veřejné vysoké školy se zřizují dle zákona č. 111/1998 Sb., o vysokých školách ve znění pozdějších předpisů. Vysoká škola může být veřejná, soukromá nebo státní. Státní vysoká škola je vojenská nebo policejní. Registrace vede Ministerstvo školství, mládeže a tělovýchovy. Ze zákona je uskutečňována činnost, která je považována za nejvyšší článek vzdělávací soustavy, školy jsou uznávány za centra vzdělanosti a nezávislého poznání a tvůrčí činnosti. Dle statutu uskutečňují své aktivity.

Jiné účetní jednotky jsou organizace, které vznikly na základě profesně zaměřeného zákona a nejsou založeny za účelem podnikání. Jejich činnost je natolik zvláštní, že nejsou zařazeny pod některou z výše jmenovaných typů organizací, ale jsou právnickými osobami a tedy účetními jednotkami. Nelze je zařadit pod zájmová sdružení, protože ze zákona je pro vybrané profese účast $\mathrm{v}$ nich povinná pro výkon povolání, jako př́klady lze uvést (lékař - Česká lékařská komora, auditor - Komora auditorů České republiky). Jejich cílem je dohled nad výkonem dané profese.

Pro přehlednost povinností spojených s registrací a organizací činností jsou jednotlivé typy seřazeny do tabulky, ze které jsou patrné možné varianty registrací u příslušných institucí a vnitřní organizace jednotlivých subjektů. Při stanovení organizačních principů je nezbytné vycházet přesně z ustanovení konkrétních zákonů a současně aplikovat chybějící metodické prvky vlastním rozhodnutím v souladu s právním prostředím. 
Tabulka 1 Registrace a organizace činnosti NNO

\begin{tabular}{|c|c|c|}
\hline Typ organizace & Registrace & Organizace činnosti \\
\hline Zájmová sdružení právnických osob & $\begin{array}{l}\text { Registr sdružení vede } \\
\text { krajský úřad }\end{array}$ & Stanovy \\
\hline Organizace s mezinárodním prvkem & Ministerstvo vnitra & Stanovy \\
\hline Občanská sdružení & Ministerstvo vnitra & Stanovy \\
\hline Politické strany a politická hnutí & Ministerstvo vnitra & Stanovy \\
\hline Společenství vlastníků jednotek & Obchodní rejstřík & Stanovy \\
\hline Obecně prospěšné společnosti & Obchodní rejstř́ík & Statut \\
\hline Nadace a nadační fondy & Nadační rejstř́ík & Statut \\
\hline Církve a náboženské společnosti & Ministerstvo kultury & Základní dokument \\
\hline Veřejné vysoké školy & $\begin{array}{l}\text { Ministerstvo školství, } \\
\text { mládeže a tělovýchovy }\end{array}$ & Statut \\
\hline Jiné účetní jednotky & Ze zákona & Ze zákona \\
\hline
\end{tabular}

Zdroj: vlastní zpracování

Srovnáváním kroků při zakládání NNO je patrna nejednotnost, nesourodost a chybějící sjednocující metodický postup. Je otázkou, zda dalším vývojem těchto specifických organizací bude pro zjednodušení a zpřehlednění vytvoření jednotného místa registrace a povinnost zveřejnění identifikačních údajů.

Analogicky při účtování a zdaňování NNO vznikají problémy při rozlišování aktivit spojených s hlavní činností a případnou doplňkovou činností, kdy povinností je účtovat odděleně o těchto dvou oblastech, pro správné stanovení základu daně je nutno přesně upravovat dle ustanovení zákona o daních z př́ijmů.

\section{4. Účetnictví nestátních nevýdělečných organizací}

Přiznaný status právnické osoby znamená současně povinnost vedení účetnictví ode dne vzniku. Za den vzniku je považováno zaregistrování do př́íslušné evidence. V souladu s $\S 1$ odst. 2 písm. a) zákona č. 563/1991 Sb., o účetnictví, ve znění pozdějších předpisů, jsou za účetní jednotku považovány právnické osoby se sídlem na území České republiky. Všechny NNO jsou tedy dle zákona o účetnictví považovány za účetní jednotku. Vedení účetnictví je náročnou činností, která vyžaduje znalosti a praktické zkušenosti, v současné době je vedeno v technické podobě, která je podmíněna základním vybavením výpočetní technikou. Možná varianta je pověřit vedením účetnictví jinou právnickou nebo fyzickou osobu, která má požadované zázemí.

NNO mohou být založeny i jediným zřizovatelem (nadace), lze tedy předpokládat, že tyto osoby nebudou disponovat dostatečným potenciálem vekonomické oblasti, jelikož se zaměřují na oblast charitativní, sociální apod. a zkušenosti ekonomického charakteru a s tím spojených povinností nejsou z jejich aspektu ty hlavní. Zde se objevuje další klíčové specifikum NNO a to rozpor mezi ekonomickým prostředím ve kterém se musí pohybovat a na jehož podmínky musí přistoupit a na straně druhé poslání poskytování služeb bez ohledu na finanční náročnost jen s uplatněním vize poskytovat za zvýhodněných podmínek služby širokému spektru potřebných spoluobčanů.

Od roku 1992 existovaly v České republice dvě účetní soustavy, jednoduché účetnictví a podvojné účetnictví. Soustava účetnictví jednoduchého byla ukončena k 31.12.2003 a od roku 2004 se zmiňuje jen účetnictví, jako jediný představitel metodických postupů založených na 
principu účtování podvojných souvztažných zápisů na účtech dle směrné účtové osnovy. V souladu s § 38a zákona č. 563/1991 Sb. o účetnictví, ve znění pozdějších předpisů, je umožněno některým organizacím, při splnění podmínek, účtovat v soustavě jednoduchého účetnictví. Pokud celkové přrijmy za poslední uzavřené účetní období nepřesáhnou 3000000 Kč, mohou

- občanská sdružení, jejich organizační jednotky, které mají právní subjektivitu,

- církve a náboženské společnosti,

- církevní instituce, které jsou církevní právnickou osobou,

- honební společenstva

účtovat v soustavě jednoduchého účetnictví v podobě platné k 31. 12. 2003 [1]. Ze skupiny NNO jsou tímto ustanovením vyňaty subjekty, na které je jinak pohlíženo, ale kterým při překročení daného limitu vzniká povinnost vedení účetnictví. Zde je na místě nutno upozornit, že nelze již zpětně při podkročení limitu v letech následujících se vrátit k jednoduchému účetnictví. Anomálie jednoduchého účetnictví zůstala zachována, i když s omezujícími podmínkami. Primárně účetní jednotky jsou povinny vést účetnictví v plném rozsahu. Jedním z klíčových specifik NNO při vedení účetnictví je možnost zvolit jednodušší formu, kdy taxativně vymezenému okruhu účetních jednotek, v souladu s $§ 9$ zákona č. 563/1991 Sb., o účetnictví, ve znění pozdějších předpisů, je povoleno vést účetnictví ve zjednodušeném rozsahu. Podmínky vedení účetnictví ve zjednodušeném rozsahu vymezuje § 13a zákona o účetnictví. Při identifikování podmínek, za kterých vedou NNO účetnictví, lze konstatovat jejich zvláštní postavení umožněním vést účetnictví ve zjednodušeném rozsahu, případně jednoduché účetnictví, jak prezentuje Tabulka 2.

Tabulka 2 Vedení účetnictví NNO

\begin{tabular}{|c|c|c|}
\hline Typ organizace & Účetnictví & $\begin{array}{c}\text { Jednoduché účetnictví } \\
\text { (při splnění podmínek) }\end{array}$ \\
\hline Zájmová sdružení právnických osob & plný rozsah & \\
\hline Organizace s mezinárodním prvkem & plný rozsah & ano \\
\hline Občanská sdružení & $\begin{array}{c}\text { zjednodušený } \\
\text { rozsah }\end{array}$ & \\
\hline Politické strany a politická hnutí & plný rozsah & \\
\hline Společenství vlastníků jednotek & $\begin{array}{c}\text { zjednodušený } \\
\text { rozsah }\end{array}$ & \\
\hline Obecně prospěšné společnosti & $\begin{array}{c}\text { zjednodušený } \\
\text { rozsah }\end{array}$ & \\
\hline Nadace & plný rozsah & \\
\hline Nadační fondy & $\begin{array}{c}\text { zjednodušený } \\
\text { rozsah }\end{array}$ & \\
\hline Církve a náboženské společnosti & $\begin{array}{c}\text { zjednodušený } \\
\text { rozsah }\end{array}$ & \\
\hline Veřejné vysoké školy & plný rozsah & ano \\
\hline Jiné účetní jednotky & $\begin{array}{c}\text { zjednodušený } \\
\text { rozsah }\end{array}$ & honební společenstva ano \\
\hline
\end{tabular}

Zdroj: vlastní zpracování

Ve srovnání s podnikatelským sektorem autorka vidí další klíčové specifikum NNO, nebot' podnikatelské subjekty právnické osoby musí vést účetnictví v plném rozsahu. 


\section{Zdaňování výsledku hospodaření nevýdělečných organizací}

$\mathrm{K}$ zásadním povinnostem vyplývajících ze vzniku nového subjektu patří registrace $\mathrm{k}$ dani z př́ijmů. I zde legislativa zvažuje specifickou situaci v NNO tím, že uvádí v daňovém řádu podmínku registrace konání činnosti, která je zdrojem př́ijmů, které jsou předmětem daně, nebo výsledky činnosti jsou předmětem daně [13]. NNO tedy dle těchto ustanovení nemusí splnit podmínku se $\mathrm{k}$ dani $\mathrm{z}$ př́ijmů registrovat. Analogicky z ustanovení zákona o daních z prríjmů [12] vyplývá, kdy pro poplatníky, kteří nejsou založeni nebo zrrízeni za účelem podnikání nevzniká povinnost podat daňové přiznání pokud:

- nemají př́ijmy, které jsou předmětem daně, nebo

- mají pouze př́ijmy od daně osvobozené.

Tedy již při vzniku NNO je důležité znát tato klíčová specifika pro usnadnění orientace v legislativě.

Při výpočtu základu daně z př́ijmů se primárně vychází z výsledku hospodaření, který je výstupem z účetnictví. Pro správné stanovení základu daně jsou nezbytné úpravy v souladu s ustanoveními zákona. U NNO platí povinnost vést účetnictví tak, aby byly vedeny odděleně příjmy, které jsou předmětem daně, od příjmů, které předmětem daně nejsou nebo předmětem daně jsou, ale jsou od daně osvobozeny [12]. Obdobně toto platí i na vykazování nákladů (výdajů). Základem daně je rozdíl, o který příjmy, s výjimkou př́ijmů, které nejsou předmětem daně, a př́ijmů osvobozených od daně, převyšují výdaje (náklady) ve věcné a časové souvislosti [12]. Toto povinné dokládání požadavků $\mathrm{z}$ hlediska daně $\mathrm{z}$ př́ijmů vede k nezbytnosti klíčování jednotlivých aktivit do skupin a stanovení jejich základů daně. Klíčování nákladů a rozlišování prŕíjmů je další ze specifik, kterou musí řešit NNO. Pro správné posouzení výpočtu daně z př́ijmů se zřetelem na NNO je tedy nezbytné:

- stanovit příjmy, které jsou předmětem daně a které předmětem daně nejsou,

- stanovit př́íjmy od daně osvobozené,

- stanovit náklady, které jsou daňově uznatelné a které nejsou daňově uznatelné,

- stanovit možnost uplatnění položek snižujících základ daně,

- stanovit možnost uplatnění slev na vypočtené dani na zaměstnance s postižením.

Lze konstatovat, že NNO i z hlediska zdaňování hospodářského výsledku mají specifické postavení, které vyplývá z jejich cíleného zaměření na poskytování veřejně prospěšných služeb, nepřinášejících zisk. Výjimkami v zákonu o daních z př́immů je zdůrazněna závažnost a význam poskytování prospěšných služeb a současně je tak projevem důvěry ze strany státu vůči těmto organizacím. Stuchlíková a Komrsková [3] tuto situaci popisují následovně „Někdy se zdaňuje př́ijem, jindy výnos, ale také rozdíl mezi př́ijmy a výdaji (zjednodušeně řečeno u těch s jednoduchým účetnictvím), nebo rozdíl mezi výnosy a náklady, anebo se pro zdanění vychází z výsledku hospodaření. To je různé a mnohdy i d’ábelské, zrádné ale i zajímavé. A je to možná i to, co dělá „,neziskovku“ tím zajímavým, neodolatelným a obávaným současně“ [3 s. 24].

\section{Závěr}

Založením a aktivní činností naplňuje nevýdělečná organizace svoje cíle. Tyto z primárních vizí vycházející konání naráží na bariery okolního prostředí, které morálně mnohdy neodpovídá zaměření organizace. Spektrum legislativních předpisů, které se týkají typu, podmínek založení a dalšího fungování, zapříčiňují metodickou nejednotnost ve srovnání s podnikatelskými subjekty, které mají relativně jednotně nastavená pravidla. Specifické postavení nestátních nevýdělečných organizací s sebou přináší nutnost flexibilního řešení situací, na jejichž výsledcích závisí další existence organizace. 
Cílem článku bylo identifikovat klíčová specifika nestátních nevýdělečných organizací v současném tržním prostředí. Nelze provozovat činnost organizace bez podrobné identifikace povinností spojených se vznikem právnické osoby, disponující majetkem a provádějící finanční a majetkové transakce. Současně se stanovením cílů je nutno splnit povinnost vedení účetnictví, př́ípadně možnost vedení účetnictví jednoduchého, zajistit úkony související $\mathrm{s}$ vedením účetnictví $\mathrm{v}$ plném nebo zjednodušeném rozsahu. Pro nestátní nevýdělečné organizace platí, že jsou považovány za účetní jednotku, což znamená řídit se systémem účetního práva. $\mathrm{Z}$ daňového aspektu jsou považovány nestátní nevýdělečné organizace za daňové poplatníky, tedy nutnost řídit se systémem daňového práva. Zajistit povinnosti registrace, sestavení daňového přiznání a jeho podání, uplatnit výjimky, které jsou relativně rozsáhlé, ale současně velmi administrativně náročné.

Nestátní nevýdělečné organizace mají své nezastupitelné místo ve společnosti, jsou financovány ze soukromých i veřejných financí a vyjadřují schopnost určité skupiny lidí záměrně ovlivňovat okolní prostředí. Stát vybranými nástroji v oblasti účetní a daňové politiky podporuje tyto organizace, ale základní úkony v řízení vyžadují profesionální přístup představitelů organizace.

\section{Literatura:}

[1] HRUŠKA, V. Účetnictví ve zjednodušeném rozsahu pro podnikatele. 1. vyd. Praha: 1. VOX, 2010, 250 s. ISBN 978-80-86324-85-2.

[2] KOČÍ, P. a kol. Meritum Nevýdělečné organizace 2011. 7. vyd. Praha: Wolters Kluwer ČR, 2011, 312 s. ISBN 978-80-7357-625-7.

[3] STUCHLÍKOVÁ, H, KOMRSKOVÁ, S. Zdaňování neziskových organizací. 8. aktualizované vyd. Olomouc: ANAG, 2011, 247 s. ISBN 978-80-7263-658-7.

[4] URBANCOVÁ, A., KRYŠKOVÁ, Š. Účetnictví nevýdělečných organizací A. 2. rozšířené a aktualizované vyd. Ostrava: VŠB-TU, 2008, 232 s. ISBN 978-80-2481801-6.

[5] Zákon č. 2/1993 Sb., Listina základních práv a svobod, ve znění pozdějších předpisů.

[6] Zákon č. 40/1964 Sb., občanský zákoník, ve znění pozdějších předpisů.

[7] Zákon č. 563/1991 Sb., o účetnictví, ve znění pozdějších předpisů.

[8] Zákon č. 248/1995 Sb., o obecně prospěšných společnostech, ve znění pozdějších př̀edpisů.

[9] Vyhláška č. 504/2002 Sb., kterou se provádějí některá ustanovení zákona č. 563/1991 Sb., o účetnictví, ve znění pozdějších předpisů, pro účetní jednotky, u kterých hlavním předmětem činnosti není podnikání, pokud účtují v soustavě podvojného účetnictví, ve znění pozdějších předpisů.

[10] Vyhláška č. 410/2009 Sb., kterou se provádějí některá ustanovení zákona č. 563/1991 Sb., o účetnictví, ve znění pozdějších předpisů, pro některé vybrané účetní jednotky, ve znění pozdějších předpisů.

[11] České účetní standardy pro účetní jednotky, které účtují podle vyhlášky č. 504/2002Sb., ve znění pozdějších předpisů (dále jen „České účetní standardy pro účetní jednotky, u kterých hlavním předmětem činnosti není podnikání“).

[12] Zákon č. 586/1992 Sb., o daních z př́ijmů, ve znění pozdějších předpisů.

[13] Zákon č. 280/2009 Sb., daňový řád.

[14] http://verejna-sprava.kr-moravskoslezsky.cz/registr_zs.html

[15] http://www.neziskovky.cz/clanek/1583/601/aktuality_homepage/zmena-pravniupravy-obecne-prospesnych-spolecnosti-od-1-1-2011/ 
[16] http://www.businessinfo.cz/cz/clanek/zakony/zakon-o-sdruzovaniobcanu/1001184/7282/

JEL M41, M42, M49.

\section{Ing. Iris Šimíková}

Odborná asistentka Katedra účetnictví

Obchodně podnikatelská fakulta v Karviné

Slezská univerzita v Opavě

Univerzitní nám. 1934/3, 73340 Karviná

simikova@opf.slu.cz 